®I. О. Крицький, Т. І. Крицький, М. Д. Процайло

ДВНЗ « Тернопільський державний медичний університет імені I. Я. Горбачевського МOЗ України»

\title{
МЕТОДИ ДІАГНОСТИКИ ТА ЛІКУВАННЯ ХІМІЧНИХ ОПІКІВ СТРАВОХОДУ ПРИ НЕОБЕРЕЖНОМУ ПОВОДЖЕННІ ДІТЬМИ 3 ПОБУТОВИМИ РІДИНАМИ
}

МЕТОДИ ДІАГНОСТИКИ ТА ЛІКУВАННЯ ХІМІЧНИХ ОПІКІВ СТРАВОХОДУ ПРИ НЕОБЕРЕЖНОМУ ПОВОДЖЕННІ ДІТЬМИ 3 ПОБУТОВИМИ РІДИНАМИ. Автори описують методи діагностики, клінічної картини та лікування опіків стравоходу та шлунка у дітей хімічними побутовими рідинами, які викликають тяжкі ускладнення в результаті своєї хімічної дії. За даними 33 спостережень, у 26 (78,0 \%) дітей розвинулись ускладнення зі сторони шлунково-кишкового тракту. Двоє дітей піддались оперативному лікуванню. Переглянуто питання діагностики та лікувальної тактики у випадках, коли діти з необережності вживають всередину хімічні побутові рідини.

МЕТОДЫ ДИАГНОСТИКИ И ЛЕЧЕНИЯ ХИМИЧЕСКИХ ОЖОГОВ ПИЩЕВОДА ПРИ НЕОСТОРОЖНОМ ОБРАЩЕНИИ ДЕТЬМИ С БЫТОВЫМИ ЖИДКОСТЯМИ. Авторы описывают методы диагностики, клинической картины и лечения ожогов пищевода и желудка у детей химическими бытовыми жидкостями, которые вызывают тяжелые осложнения в результате своего химического действия. По данным 33 наблюдений, у 26 (78,0 \%) детей развились осложнения со стороны желудочно-кишечного тракта. Двое детей поддалось оперативному лечению. Пересмотрен вопрос диагностики и лечебной тактики в случаях, когда дети по неосторожности употребляют внутрь химические бытовые жидкости.

METHODS OF DIAGNOSIS AND TREATMENT OF ESOPHAGEAL CHEMICAL BURNS IN CHILDREN WHO CARELESSLY USED HOUSEHOLD LIQUIDS. The authors describe methods of diagnosis, clinical presentation and treatment of burns of the esophagus and stomach in children with household chemical fluids that cause severe complications as a result of their chemical action. Of the 33 observations in $26(78.0 \%)$ children developed complications on the part of the gastrointestinal tract. Two children were subjected to surgical treatment. Questions of diagnosis and treatment strategy where reviewed, in cases when children where taking into household chemical liquid.

Ключові слова: опік, стравохід, шлунок, побутові рідини, ускладнення, діти.

Ключевые слова: ожог, пищевод, желудок, бытовые жидкости, осложнения, дети.

Key words: burn, esophagus, stomach, household chemical liquids, complication, children.

ВСтУП. За останні роки значно збільшилась частота випадків опіку ставоходу різноманітними рідинами. Опік стравоходу розвивається тоді, коли в нього потрапляють деякі хімічні речовини. Як правило, це відбувається або випадково, або при спробі суїциду. Медична статистика свідчить, що серед загальної кількості людей, які отримали опіки стравоходу, 70,0 \% складають діти, яким ще не виповнилося 10 років. Настільки велика кількість постраждалих дітей пояснюється недоглядом дорослих і звичкою маленьких дітей «пробувати» все на смак.

Мета дослідження - вироблення діагностичної та лікувальної тактики при хімічних опіках ставоходу та шлунка в дітей.

МАТЕРІАЛИ ТА МЕТОДИ. У відділенні дитячої хірургї̈ КУТОР «ТОДКЛ» за період з 2010 по 2014 рік перебувало на лікуванні 33 дитини 3 хімічними опіками ставоходу та шлунка віком від 3 до 17 років. В ургентному порядку госпіталізовано всі 33 дитини. У всіх дітей при наявності скарг на вживання хімічношкідливих побутових рідин вивчався анамнез, проводилися стандартні методи обстеження: оглядова рентгенографрія грудної та черевної порожнин, фріброезофагогастродуоденоскопія, загальний аналіз крові та сечі.

РЕЗУЛЬТАТИ ДОСЛІДЖЕННЯ ТАЇХ ОБГОВОРЕН-

ня. При аналізі контингенту хворих звертає на себе увагу те, що серед них переважали пацієнти віком від 3 до 7 років - 78,5\%, від 7 і більше - 21,5\%.

Попередній діагноз встановлювали на підставі анамнезу та оцінки тяжкості загального стану хворого. Характерїдкої рідини, прийнятоїдитиною, визначали з її слів або слів батьків, або за залишками рідини, що знаходилася в посудині (чашка, пляшка), 3 якої хворий її пив.

Перші й найбільш яскраві симптоми - сильне печіння і біль у порожнині рота, глотки, за грудниною і в епігастральній ділянці, що виникають відразу після проковтування їдкої речовини.

У тяжких випадках (13) розвивалися шок та втрата свідомості. Якщо протягом 1-2 днів у хворого з'являються виражена задишка внаслідок набряку гортані, блювота слизом і кров'ю, в блювотних масах визначаються шматочки слизової оболонки. Підвищується температура тіла. Ковтання не можливе. У результаті глибокого ураження стінки стравоходу можливі кровотечі, симптоми, зумовлені розвитком медіастиніту або інших ускладнень, порушення функції нирок (внаслідок їх токсичного ураження).

У випадках середньої тяжкості (10) через кілька днів зменшується біль, проте ковтання утруднене, відзначаються підвищена салівація, зригування кров'янистими виділеннями. При огляді порожнини рота видно сліди опіку слизової оболонки. Через 10 - 


\section{Педіатрія}

20 днів поступово відновлюється здатність ковтати рідину і рідку їжу, проте ковтання довго залишається болючим. У період рубцювання, через кілька тижнів, дисфагія відновлюється; при різкому стенозуванні стравоходу хворий не може приймати рідину та їжу, розвивається виснаження.

При тяжких отруєннях їдкими речовинами можуть спостерігатися летальні випадки внаслідок інтоксикації, шоку, розвитку гнійних ускладнень (медіастиніт, абсцес і гангрена легені, плеврит). 3 ускладнень можуть виникати тяжкі кровотечі стравоходу, перфорації стравоходу, розвиватися стравохідно-трахеальні та стравохідно-бронхіальні нориці. Найбільш частим пізнім ускладненням хімічних опіків стравоходу $є$ розвиток рубцевих звужень (стенозів) стравоходу, його рубцевих деформацій і вкорочення.

Відомі труднощі в діагностиці виникали у маленьких дітей, які не в змозі надати відомості про характер випитої рідини. Так само в гострий період на підставі тільки клінічних симптомів не можна припускати або заперечувати наявність опіку стравоходу. Невідомо, чи проковтнула дитина хімічну речовину або взяла у рот і виплюнула, бо при ізольованому опіку порожнини рота і при опіку стравоходу можуть бути одні й ті ж симптоми. Тому діагностика опіків стравоходу повинна ґрунтуватися не тільки на клінічних симптомах, але насамперед на даних об'єктивного дослідження - діагностичної фіброезофагогастроскопії, яка виконується в умовах стаціонару.

Всім хворим дітям з хімічними опіками побутовими речовинами показана невідкладна терапія: необхідні термінова госпіталізація, парентеральне введення знеболюючих засобів (для боротьби з шоком), введення шлункового зонда, добре змащеного олією, для видалення шлункового вмісту та промивання шлунка 3 метою нейтралізації їдкої речовини. При отруєннях лугами шлунок промивають розведеним розчином оцтової кислоти (3-6 \%) або рослинною олією, при отруєннях кислотами - слабким (2 \%) розчином натрію гідрокарбонату. В сумнівних випад- ках шлунок промивають молоком. До введення зонда призначають пиття у великій кількості слабких розчинів оцтової кислоти чи бікарбонату натрію (залежно від характеру отрути) або ж молока (0,5-1,0 склянка). Промивання за допомогою зонда проводять після попереднього введення наркотичних анальгетиків (промедол 1 мл 2 \% розчину) і атропіну сульфату (1,0 мл 0,1 \% розчину), а також місцевої анестезії порожнини рота і глотки 2,0 \% розчином дикаїну. Промивання шлунка ефективне тільки в перші 6 год після отруєння. Необхідна дезінтоксикаційна терапія. Парентерально вводять гемодез, реополіглюкін, сольові розчини. Для профілактики і лікування інфекційних ускладнень призначають парентерально антибіотики широкого спектра дії (цефтріаксон, амікацин та ін.). Щоб зменшити розвиток рубцевих змін у стравоході, призначають препарати гормонів кори надниркових залоз парентерально.

ВИсновкИ. 1. Хімічні побутові рідини $є$ небезпечними для дітей - можуть викликати опіки та інші тяжкі ускладнення стравоходу і шлунка, що загрожують їх життю.

2. Езофагоскопія в перші дні протипоказана, надалі можлива тільки в період рубцювання та епітелізації слизової оболонки, при цьому проводити її слід вкрай обережно.

3. Усіх дітей, які в анамнезі вживали випадково чи спеціально хімічні побутові рідини, необхідно госпіталізувати ургентно в стаціонар у відділення реанімації і застосувати до них невідкладну допомогу.

ПЕРСПЕКТИВИ ПОДАЛЬШИХ ДОСЛІДЖЕНЬ. ПОдальше вивчення та вдосконалення методів діагностики і лікувальної тактики у дітей при хімічних опіках стравоходу та шлунка дадуть змогу максимально покращити корекцію цієї патології і можливих ускладнень та в деяких випадках врятують життя дитини. Розробка та вдосконалення нових методів діагностики і лікування хімічних опіків стравоходу в дітей дозволять своєчасно розпочати лікування та профілактику цієї патології.

\section{СПИСОК ЛІТЕРАТУРИ}

1. Богопольский П. М. Хірургія стравоходу : керівництво для лікарів / П. М. Богопольский, Ф.С.Курбанов. - М. : Медицина, 2001.

2. Клінічна токсикологія дітей та підлітків : навчальний посібник : в 2 т. / за ред. І. В. Маркової. - СПб., 1998.

3. Кравчук Б. О. Електрохімічній опік стравоходу в дітей / Б. О. Кравчук, В. А. Дамарніцький // Хірургія дитячого віку. - 2009. - Т. 4, № 2 (23). - С. 66-70.
4. Кривченя Д. Ю. Сторонні тіла травного тракту в дітей / Д. Ю. Кривченя, О. Г. Дубровін // Хірургічні аспекти захворювань кишечнику в дітей. - Чернівці, 2008. - C. 27-28.

5. Нікітаєв В. І. Ендоскопічна тактика при сторонніх тілах верхніх відділів ШКТ / В. І. Нікітаєв, А. М. Задорожній // Український журнал малоінвазивної та ендоскопічної хірургії. - 2006. - Т. 10, № 2. - С. 40-46. 